\section{EFEKTIFITAS PENERAPAN BLENDED LEARNING DALAM MENINGKATKAN MOTIVASI BELAJAR MAHASISWA SASTRA INGGRIS UNIVERSITAS KHAIRUN}

\author{
Sulmi Magfirah \\ Universitas Khairun
}

Email: magfirahsulmi@gmail.com

\begin{abstract}
Abstrak. Blended learning merupakan model pembelajaran yang bisa diterapakan dosen guna mengoptimalkan capaian hasil pembelajarannya. Penelitian yang berjudul "Efektifitas Penerapan Blended Learning dalam Meningkatkan Motivasi belajar Mahasiswa" ini bertujuan untuk rnengetahui sejauh mana efektifitas Blended Learning dalam meningkatkan motivasi belajar mahasiswa semester 1 (satu) Program Studi Sastra Inggris Universitas Khairun. Penelitian yang dilaksanakan pada Prodi Sastra Inggris merupakan penelitian eksperirnen semu yang dirancang dengan menggunakan nonequivalent control group design. Sebanyak 50 orang mahasiswa semester 1 menjadi sample pada penelitian ini. Sample tersebut kemudian terbagi kedalam 2 (dua) kelas, yaitu kelas ekperimen yang diaplikasikan menggunakan blended learning dan kelas kontrol yang menggunakan pembelajaran manual atau tatap rnuka, masing-masing terdiri dari 25 orang mahasiswa. Angket motivasi belajar mahasiswa digunakan sebagai instrurnen untuk mengumpulkan data yang terkait motivasi belajar mahasiswa. Hasil penelitian menunjukkan bahwa terdapat perbedaan yang signifikan antara motivasi belajar mahasiswa pada kelas eksperimen dan mahasiswa pada kelas kontrol setelah diberikan perlakuan yang berbeda. Peneliti juga menemukan bahwa penerapan Blended Learning efektif diaplikasikan dalam meningkatkan motivasi belajar mahasiswa semester 1 Prodi Sastra Inggris Universitas Khairun.
\end{abstract}

Kata Kunci: Gaya Belajar, Hasil Belajar, Reading Comprehension
INTERFERENCE

Journal of Language,

Literature, and

Linguistics

\author{
E-ISSN: 2721-1835 \\ P-ISSN: 2721-1827 \\ Submitted: July $10^{\text {th }}, 2020$ \\ Accepted : August 11 ${ }^{\text {th }}, 2020$
}

Abstract. Blended learning is a learning model that lecturers can apply to optimize the learning outcomes. This study, entitled "The Effectiveness of Blended Learning to Increase Student Motivation" aims to determine the extent of the effectiveness of Blended Learning in increasing the learning motivation on the first semester students of the English Literature Study Program at Khairun University. This research was carried out at the English Literature Study Program a quasi-experimental study designed on using the non-equivalent control group design. A total of 50 on the first semester students were sampled in this study. The sample was divided into 2 classes, experimental class used blended learning and the control class used face-to-face learning, each consisted of 25 students. The learning motivation questionnaire was used as the instrument in collecting the data related to students learning motivation. The results showed that there were significant differences between students learning motivation in the experimental class and students in the control class after had been given different treatments. The researcher also found that the application of Blended Learning was effective in increasing the learning motivation of the first semester students of English Literature Study Program at Khairun University. 


\section{PENDAHULUAN}

Sistem Revolusi industri 4.0 merupakan sistem kehidupan yang bertumpuh pada jaringan internet, yang memberikan dampak pendidikan khususnya pada sistem pengajaran dan pembelajaran. Dalam hal ini, pembelajaran merupakan sebuah perubahan dalam diri seseorang yang disebabkan oleh pengalaman. Menurut Hanifah (2011: 9), pemahaman tentang pembelajaran, akan menentukan filosofi pendidikan, gaya mengajar, pendekatan, metode dan teknik mengajar di kelas. Sehingga dalam prakteknya, semua komponen tersebut bergerak sekaligus dalam suatu rangkaian kegiatan pembelajaran yang terarah dalam rangka membawa pertumbuhan dan perubahan kepada mahasiswa berdasarkan pada tujuan yang diinginkan.

Model pembelajaran yang pada dasarnya adalah bentuk pembelajaran yang dirancang mulai dari awal sampai akhir yang disajikan dengan ciri khas tersendiri dari seorang dosen atau instruktur. Kegiatan pembelajaran dengan cara manual atau dalam bentuk tatap muka dan online (blended learning) adalah kegiatan pembelajaran yang ditetapkan dalam kelas, yang berupa proses interaksi antara mahasiswa dengan dosen.

Blended Learning merupakan program pendidikan formal yang memungkinkan peserta didik belajar secara daring melalui konten dan petunjuk yang disampaikan secara daring dan juga luring yang fleksibel terhadap waktu, tempat, maupun kecepatan belajar. Walau masih menghadiri ruang kelas, metode tatap muka ruang kelas dikombinasikan dengan aktivitas daring yang bisa diakses melalui komputer dan smartphone, sehingga memacu output atau capaian pembelajaran mahasiswa. Penelitian sebelumnya yang mengkaji tentang Blended Learning dilakukan oleh (Sandi, 2012; Idris, 2018; Fitri, Ifdil, \& Neviyarni, 2016; Dwiyogo,2015) bahwa blended learning memberikan pengaruh dalam meningkatkan motivasi dan prestasi belajar siswa.

Selain pembelajaran tatap muka di kelas, terdapat pula penggunaan system kelas daring yaitu dengan menggunakan aplikasi Learning Management System (LMS); sebuah perangkat untuk membuat materi pernbelajaran berbasis web yang mengelolah kegiatan pembelajaran beserta hasilnya dan menfasilitasi interaksi antara dosen dan mahasiswa. Mengajar online adalah satu cara mengajar inovatif yang bisa di coba dan di kembangkan. Mengajar online ini dimana seorang dosen/ instruktur berada di tempat lain.

Terdapat beberapa kelebihan menggunakan LMS, diantaranya; Media yang bervariasi, informasi yang diberikan up-to-date, komunikasi yang nyaman, biaya rendah, menghemat waktu, mengurangi kelelahan, dapat mengajar dari jauh. Namun demikian, terdapat juga bebrapa kekurangan diantaranya; mengharuskan ada jaringan/ koneksi internet ditempat belajar mengajar, dosen atau instrukturnya tidak gaptek, dan akses secara berkala.

Pembelajaran tatap muka merupakan tindakan yang dirancang untuk mendukung proses belajar peserta didik secara manual atau tatap muka. Kegiatan ini merupakan kegiatan pembelajaran yang berupa proses interaksi antara peserta didik dengan pendidik. Secara umum, terdapat dua strategi pembelajaran tatap muka yaitu strategi yang berpusat pada guru (teacher centre oriented) dan 
strategi yang berpusat pada peserta didik (student centre oriented).

Dalam metode pembelajaran Blended Learning, terdapat interaksi secara langsung berupa diskusi langsung melalui daring dan luring dalam proses belajar mengajar. Hal ini dapat menjadi solusi dalam mengatasi masalah pendidikan di Indonesia khususnya pemerataan pendidikan di Indonesia. Dengan adanya metode Blended Learning, pembelajaran dapat dilakukan secara fleksibel dimana saja dan kapan saja, selama tersedia akses internet. Selain itu, mahasiswa juga dapat mengakses materi secara leluasa dan dituntut dapat belajar secara mandiri karena bahan ajar yang dipersiapkan oleh dosen sudah tersirnpan secara online, sehingga antara pendidik dan peserta didik dapat saling memberikan feedback baik berupa pertanyaan dan saran secara realtime. Selanjutnya, diskusi serta tanya jawab antara pendidik dan peserta didik tidak hanya berlangsung di jam pelajaran namun juga dapat berlangsung di luar jam pelajaran. Dosen dapat mengontrol proses pembelajaran mahasiswa, oleh karena itu mahasiswa dapat menggali materi yang disampaikan dan proses pemberiaan tugas pendukung dapat diinformasikan dengan lebih mudah. Tentunya, proses belajar mengajar menjadi lebih efisien dan lebih efektif karena komunikasi dan interaksi antara dosen dan mahasiswa dapat terus terjadi bukan hanya saat jam pelajaran berlangsung.

Ketidakberagaman media pembelajaran, rendahnya motivasi mahasiswa dalam pembelajaran Bahasa Inggris yang mana merupakan Bahasa Asing untuk peserta didik di fakultas ilmu budaya serta anggapan media pembelajaran yang kurang menarik, sehingga menjadikan penulis menerapkan metode Blended Learning dalam mata kuliah Interactive Conversation. Penerapan ini bertujuan untuk memperkenalkan web pembelajaran kepada mahasiswa serta kepekaan terhadap penggunaan teknologi dalam sistem pembelajaran.

Berdasarkan fakta-fakta tersebut, penelitian dengan judul "Efektifitas Penerapan Blended Learning dalam Meningkatkan Motivasi Belajar Mahasiswa" dilaksanakan. Penelitian tersebut diharapkan menjawab rumusan masalah berupa:

Apakah penerapan pembelajaran dengan metode Blended Learning efektif dalam meningkatkan motivasi belajar mahasiswa semester 1 Prodi Sastra Inggris Universitas Khairun?

\section{METODE PENELITIAN}

Penelitian ini menggunakan rancangan eksperirnen semu nonequivalent control group design dengan menggunakan sample dua kelas yaitu kelas eksperimen dan kelas kontrol. Mahasiswa pada kelas eksperimen diajarkan menggunakan Blended Learning sedangkan kelas kontrol menggunakan metode pembelajaran tatap muka. Desain penelitian secara ringkas digambarkan pada Tabel 1 berikut ini:

Tabel 1. Desain Penelitian

\begin{tabular}{cccc}
\hline Kelas & Tes Awal & Perlakuan & Tes Akhir \\
\hline Eksperimen & Ya & Blended learning & Ya \\
\hline Kontrol & Ya & Pembelajaran tatap muka & Ya \\
\hline
\end{tabular}


Kedua sampel yang digunakan pada penelitian ini adalah mahasiswa semester 1 kelas A dan B dari Program Studi Sastra Inggris tahun pelajaran 2019/2020 yang mana tiap sample berjumlah 25 orang. Dari kedua kelas tersebut digunakan kelas A sebagai kelas eksperimen dan kelas B digunakan sebagai kelas kontrol. Pemilihan kedua kelas ini karena seluruh mahasiswa pada kelas tersebut memiliki level kognitif yang cukup.

Data terkait motivasi belajar mahasiswa dikumpulkan dengan menggunakan instrumen angket motivasi. Angket tersebut diadaptasi dari Tuan et al. (2005) yang terdiri dari 35 butir pernyataan yang dikategorikan ke dalam enam hal, yaitu keefektifan pribadi strategi pembelajaran aktif, nilai pembelajaran bahasa, tujuan tindakan, tujuan berprestasi, dan stimulus lingkungan pembelajaran. Data yang diperoleh selanjutnya dianalisis menggunakan Statistical Product and Service Solution (SPSS) 23.0.

\section{HASIL DAN PEMBAHASAN}

\section{Deskripsi Data Motivasi Awal Mahasiswa}

Data motivasi awal mahasiswa pada kedua sample kelas diperoleh dari angket motivasi belajar mahasiswa yang dibagikan sebelum pembelajaran dilaksanakan. Data ini bertujuan untuk melihat kesetaraan motivasi yang dimiliki oleh seluruh sampel pada kedua kelas. Adapun ringkasan data motivasi awal mahasiswa pada sample kelas eksperimen dan kelas Control dapat dilihat pada Tabel 2 berikut:

Tabel 2 Data Motivasi Awal Mahasiswa

\begin{tabular}{|c|c|c|c|c|c|c|}
\hline \multirow{2}{*}{ No. } & \multirow{2}{*}{ Kategori } & \multirow{2}{*}{$\begin{array}{c}\text { Rentan } \\
\text { nilai }\end{array}$} & \multicolumn{2}{|c|}{ Kelas Eksperimen } & \multicolumn{2}{|c|}{ Kelas Kontrol } \\
\hline & & & $\mathrm{F}$ & $\%$ & $\mathrm{~F}$ & $\%$ \\
\hline 1. & $\begin{array}{l}\text { Sangat } \\
\text { Tinggi }\end{array}$ & $86-100$ & 0 & 0.00 & 0 & 0.00 \\
\hline 2. & Tinggi & $71-85$ & 1 & 4.00 & 0 & 0.00 \\
\hline 3 & Rata-rata & $56-70$ & 11 & 44.00 & 12 & 48.00 \\
\hline 4. & Rendah & $41-55$ & 13 & 52.00 & 10 & 40.00 \\
\hline 5. & $\begin{array}{l}\text { Sangat } \\
\text { Rendah }\end{array}$ & $<40$ & 0 & 0.00 & 3 & 12.00 \\
\hline & Total & & 25 & $100 \%$ & 25 & $100 \%$ \\
\hline
\end{tabular}

Data pada Tabel 2 menunjukkan bahwa motivasi awal mahasiswa pada kelas eksperimen dan kelas kontrol cenderung setara. Sebagaian besar mahasiswa pada kedua kelas memiliki motivasi yang dikategorikan rata-rata. 11 (44\%) mahasiswa pada kelas ekperimen dan 12 (48\%) mahasiswa pada kelas kontrol mendapatkan nilai tersebut. Akan tetapi, untuk mengetahui ada perbedaan yang signifikan atau tidak pada data motivasi awal mahasiswa, maka perlu dilakukan uji $\mathrm{t}$ (t-test) pada SPSS. Uji $t$ yang dilakukan adalah independent sample t-test karena 
data tersebut berdistribusi normal dan homogen (Creswell, 2009). Adapaun hasil dari independent somyle t-test dapat dilihat pada Tabel 3 di bawah ini:

Tabel 3. Hasil Uji-t dan Motivasi Awal Mahasiswa

\begin{tabular}{lccccc}
\hline \multicolumn{1}{c}{ Kelas } & Mean & $\alpha$ & Sig (2-tailed) & Kriteria & Kesimpulan \\
\cline { 1 - 2 } Eksperimen & 55.16 & 0.05 & 0.371 & $a<$ sig & $\begin{array}{c}\text { Tidak ada } \\
\text { perbedaan }\end{array}$ \\
\hline
\end{tabular}

Tabel 3 di atas menunjukkan bahwa tidak ada perbedaan pada motivasi awal mahasiswa pada sample kelas eksperimen dan kelas kontrol, dengan kata lain motivasi belajar mahasiswa pada kedua sample kelas sama sebelum mendapat perlakuan.

\section{Deskripsi Data Motivasi Belajar Akhir Mahasiswa}

Data motivasi akhir mahasiswa diperoleh dari data angket motivasi belajar mahasiswa yang dibagikan setelah mendapatkan perlakuan di experimen kelas. Data ini kemudian digunakan untuk mengetahui perbedaan motivasi belajar mahasiswa dengan menerapkan dua metode berbeda, yaitu Blended Learning pada kelas ekspereimen dan pembelajaran tatap muka pada kelas kontrol . Ringkasan data motivasi akhir mahasiswa dapat dilihat pada Tabel 4, sebagai berikut:

Tabel 4. Data Motivasi Akhir Mahasiswa

\begin{tabular}{|c|c|c|c|c|c|c|}
\hline \multirow[t]{2}{*}{ No. } & \multirow[t]{2}{*}{ Kategori } & \multirow{2}{*}{$\begin{array}{c}\text { Rentan } \\
\text { nilai }\end{array}$} & \multicolumn{2}{|c|}{$\begin{array}{c}\text { Kelas } \\
\text { Eksperimen }\end{array}$} & \multicolumn{2}{|c|}{ Kelas Kontrol } \\
\hline & & & $\mathrm{F}$ & $\%$ & $\mathrm{~F}$ & $\%$ \\
\hline 1. & $\begin{array}{l}\text { Sangat } \\
\text { Tinggi }\end{array}$ & $86-100$ & 2 & 8.00 & 0 & 0.00 \\
\hline 2. & Tinggi & $71-85$ & 12 & 48.00 & 5 & 20.00 \\
\hline 3. & Rata-rata & $56-70$ & 11 & 44.00 & 17 & 68.00 \\
\hline 4. & Rendah & $41-55$ & 0 & 0.00 & 3 & 12.00 \\
\hline 5. & $\begin{array}{l}\text { Sangat } \\
\text { Rendah }\end{array}$ & $<40$ & 0 & 0.00 & 0 & 0.00 \\
\hline & Total & & 25 & $100 \%$ & 25 & $100 \%$ \\
\hline
\end{tabular}

Tabel 4 menunjukkan bahwa terdapat perbedaan rerata motivasi belajar akhir mahasiswa setelah diberikan perlakuan yang berbeda. Dari Tabel 5 diperoleh bahwa rata-rata mahasiswa pada kelas eksperirnen memiliki motivasi yang tinggi sedangkan motivasi belajar mahasiswa pada kelas kontrol masih dikategorikan ratarata. Selain itu, terdapat 2 orang mahasiswa dari kelas eksperimen yang menunjukkan motivasi belajarnya meningkat menjadi kategori sangat tinggi. Hal ini kemudian menunjukkan terjadi perbedaan rnotivasi belajar mahasiswa kelas eskperimen dan kelas kontrol setelah diberikan perlakuan yang berbeda.

Untuk menguatkan pernyataan terkait motivasi belajar akhir mahasiswa yang berbeda setelah diberikan perlakuan. Maka selanjutnya data motivasi akhir 
dianalisis dengan menggunakan independent Sample t-test, dengan alasan data terkait motivasi telah terdistribusi normal dan homogen. Hasil analisis tersebut dapat dilihat dari Tabel 5 berikut ini:

Tabel 5. Hasil Uji-t Data Motivasi Akhir Mahasiswa

\begin{tabular}{|c|c|c|c|c|c|}
\hline Kelas & Mean & $a$ & Sig (2-tailed) & Kriteria & Kesimpulan \\
\hline Eksperimen & 73.60 & \multirow{2}{*}{0.05} & \multirow{2}{*}{0.000} & \multirow{2}{*}{$a<\operatorname{sig}$} & \multirow{2}{*}{$\begin{array}{c}\text { Ada perbedaan } \\
\text { signifikan }\end{array}$} \\
\hline Kontrol & 63.16 & & & & \\
\hline
\end{tabular}

Berdasarkan hasil data pada Tabel 5 , nilai sig 0,00 lebih kecil dari nilai $\mathrm{n}$ 0,05, sehingga dapat ditarik kesimpulan bahwa $\mathrm{H}_{0}$ ditolak dan $\mathrm{H}_{1}$ diterima. Dengan kata lain, bahwa pembelajaran yang menerapkan Blended Learning efektif dalam meningkatkan motivasi belajar mahasiswa. Temuan ini konsisten dengan temuantemuan penelitian sebelumnya, diantaranya penelitian Frafika Sari, I., Rahayu, A., Apriliandari, D. I., \& Dwi, S. (2018); Sjukur, S. B. (2012); dan Alhazbi (2015).

Pada pembelajaran tatap muka di kelas kontrol, dosen bertindak sebagai pemberi materi utama atau dengan kata lain memiliki fungsi mengajar. Mahasiswa lebih banyak diam untuk mendengarkan dan memiliki sedikit kesempatan bertanya. Di sisi lain, pada Blended Learning di kelas eksperimen, mahasiswa mengatur ritme pembelajarannya sendiri. Dosen lebih banyak berperan sebagai pemantau dan memberi bantuan jika diperlukan atau memiliki fungsi membimbing. Saat pembelajaran Blended Learning diterapkan di kelas eksperimen yang sebelumnya terbiasa mengalami pembelajaran tatap muka, proses belajar mengajar berubah dari teacher-center oriented atau berpusat pada dosen menjadi student-center oriented atau berpusat pada mahasiswa. Hal ini mengubah pula peran mahasiswa dari pembelajar pasif ke pembelajar aktif. Pembelajaran bermakna yang dibangun dalam proses ini berdampak baik bagi motivasi belajar mahasiswa.

\section{KESIMPULAN}

Berdasarkan hasil penelitian diperoleh kesimpulan sebagai berikut:

1. Terdapat perbedaan yang signifikan antara motivasi belajar mahasiswa pada sample kelas eksperimen dan sample kelas Kontrol setelah masing-making diberikan perlakuan.

2. Penerapan Blended Learning efektif dalam meningkatkan motivasi belajar mahasiswa semester 1 pada Program Studi Sastra Inggris Universitas Khairun.

\section{DAFTAR PUSTAKA}

Alhazbi, S. (2016). Active blended learning to improve students' motivation in computer programming courses: A case study. In Advances in engineering education in the Middle East and North Africa (pp. 187-204). Springer, Cham.

Creswell, J.W. (2009). Research Design Qualitative, Quantitative, and Mixed Method Approaches 3th edition. United States of America: SAGE Publications, Inc.

Dwiyogo, W. D. (2015). Analisi Kebutuhan Pengembangan Model Rancangan 
Pembelajaran Berbasis Blended Learning (PBBL) Untuk Meningkatkan Hasil Belajar Pemecahan Masalah. Jurnal Pendidikan dan Pembelajaran (JPP), 21(1), 71-78.

Fitri, E., Ifdil, I., \& Neviyarni, S. (2016). Efektivitas layanan informasi dengan menggunakan metode blended learning untuk meningkatkan motivasi belajar. Jurnal Psikologi Pendidikan dan Konseling: Jurnal Kajian Psikologi Pendidikan dan Bimbingan Konseling, 2(2), 84-92.

Frafika Sari, I., Rahayu, A., Apriliandari, D. I., \& Dwi, S. (2018). Blended Learning: Improving Student's Motivation in English Teaching Learning Process. International Journal of Languages' Education and Teaching, 6(1), 163-170.

Hanifah, N. (2011). Bahasa, Belajar, dan Pengajaran Bahasa.

Idris, H. (2018). Pembelajaran Model Blended Learning. Jurnal IImiah Iqra', 5(1).

Sandi, G. (2012). Pengaruh blended learning terhadap hasil belajar kimia ditinjau dari kemandirian siswa. Jurnal Pendidikan dan Pengajaran, 45(3).

Sjukur, S. B. (2012). Pengaruh blended learning terhadap motivasi belajar dan hasil belajar siswa di tingkat SMK. Jurnal pendidikan vokasi, 2(3).

Tuan, H.L., Chin, C.C. \& Shieh, S. H. (2005). The Development of a Questionnaire to Measure Students' Motivation towards Science Learning. International Journal of Science Education, 27(6): 639-654 